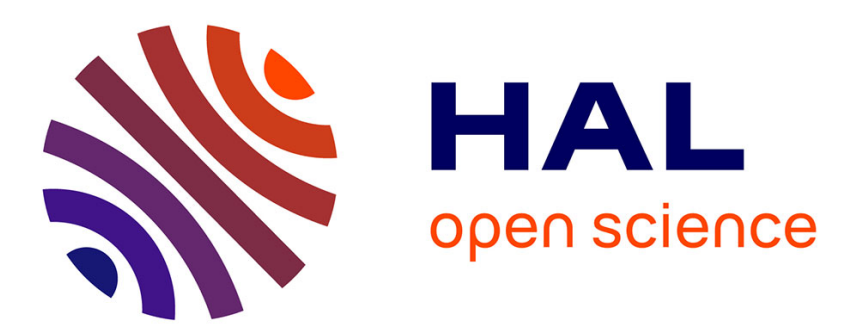

\title{
Are we neglecting local knowledge while choosing rehabilitation strategy for mining sites? \\ Vaja Pavlovic
}

\section{To cite this version:}

Vaja Pavlovic. Are we neglecting local knowledge while choosing rehabilitation strategy for mining sites?. EGU General Assembly 2021, Apr 2021, online, France. 10.5194/egusphere-egu21-6613 . hal03209130

\section{HAL Id: hal-03209130 \\ https://hal.sorbonne-universite.fr/hal-03209130}

Submitted on 27 Apr 2021

HAL is a multi-disciplinary open access archive for the deposit and dissemination of scientific research documents, whether they are published or not. The documents may come from teaching and research institutions in France or abroad, or from public or private research centers.
L'archive ouverte pluridisciplinaire HAL, est destinée au dépôt et à la diffusion de documents scientifiques de niveau recherche, publiés ou non, émanant des établissements d'enseignement et de recherche français ou étrangers, des laboratoires publics ou privés. 


\title{
EGU21-6613
}

https://doi.org/10.5194/egusphere-egu21-6613

EGU General Assembly 2021

(c) Author(s) 2021. This work is distributed under

the Creative Commons Attribution 4.0 License.

\section{Are we neglecting local knowledge while choosing rehabilitation strategy for mining sites?}

\author{
Vaja Pavlovic \\ Sorbonne University, France (vajapavlovic@gmail.com)
}

Given that mining sites, active or closed, represent almost 1 percent of Earths' surface, the choice of adequate rehabilitation strategy is of crucial importance. In our previous work, we were examining the types of rehabilitation and biodiversity developed in consequence, and suggested that natural succession should be favoured whenever possible.

As advocated by IPBES, in its report of the second session of the plenary meeting (2012), indigenous and local knowledge should be valued and taken into account in decision-making processes, in order to stop the biodiversity loss. Yet, the decisions on rehabilitations are being taken by environmental professionals, without consulting with site managers. In this study, we were examining whether there is a local knowledge, which could be used when choosing the adequate rehabilitation technique. We were interested in how quarries and sand and gravel pits managers apprehend biodiversity, since they are the ones conducting actions impacting biodiversity. We were interested in their apprehension of their own actions and its consequences on biodiversity.

Managers of 46 quarries and sand and gravel pits were interviewed, on site, using Critical Incident Technique (Flanagan, 1954), in order to obtain examples of concrete situations showing their relationship with biodiversity as well as their degree of conscience on biodiversity issues. Every interview lasted about one hour and a half and consisted of two parts: the first where general questions were asked in the office for about 15 minutes and the second where the questions about the situations related to biodiversity were asked, during the walk around the site for better contextualization.

We analyzed the collected data using Grounded Theory (Glaser et al. 1967) which is a method used to analyze the field data (e.g. interviews), in order to obtain a theory that explains the underlying phenomenon. Often used in social sciences in order to understand the phenomena and identify the paradigms, this method was well adapted to reveal the causes and motivations of actions conducted by site managers.

Results of this study allowed us to comprehend the site managers as not just actors at the source of impact on biodiversity, but also as actors that are informed and that invest themselves in a relationship with nature. They perceive the value of biodiversity in quarries and gravel pits, conduct a lot of non-mandatory actions for biodiversity, during the life cycle of the site and are 
motivated to conduct additional measures in order to favor biodiversity. We discovered that there is a hidden expertise among site managers. For instance, they are capable of recognizing a lot of animal species present on site and even to predict the failure of certain rehabilitation techniques.

Following this conclusion, it seems unfortunate that the experience of site managers is not used when choosing the type of rehabilitation. A more participatory, interactive and more educational two-way process would seem much more appropriate for this type of actors who are very important for the implementation of biodiversity protection policies and who see themselves more proactive than reactive. 